УДК 316.4

DOI: 10.18101/1994-0866-2019-4-64-70

\title{
МЕЖЭТНИЧЕСКАЯ ТОЛЕРАНТНОСТЬ И СОГЛАСИЕ КАК ТРАДИЦИЯ БУРЯТИИ
}

\section{(C) Чимитова Ирина Зоригтоевна}

кандидат социологических наук, старший преподаватель, Бурятская государственная сельскохозяйственная академия им. В. Р. Филиппова Россия, 670024, г. Улан-Удэ, ул. Пушкина, 8

E-mail: rindaol@mail.ru

\section{(С Серебрякова Юлия Александровна}

доктор философских наук, профессор, Бурятская государственная сельскохозяйственная академия им. В. Р. Филиппова Россия, 670024, г. Улан-Удэ, ул. Пушкина, 8

E-mail: serebr.yu.a@yandex.ru

В качестве одного из факторов межэтнической толерантности и согласия применительно к ряду российских регионов, в том числе Бурятии, можно рассматривать традиции позитивного межэтнического взаимодействия, сложившиеся там. В Бурятии такие отношения, в том числе между крупнейшими по численности народами - бурятами и русскими, являются традиционными в силу нескольких причин: изначальной готовности к контактам аборигенов этого региона, специфики природно-географических условий, близкого соседства и сотрудничества народов, следствиями которых были взаимный обмен опытом, смешанные браки и т. д. В процессе постоянного взаимодействия вырабатывались и закреплялись алгоритмы поведения, определенные правила, нормы и т. д., которые становились стереотипами, в сознании складывались взаимные образы другого народа. Наиболее адекватные образы и самые удачные алгоритмы закреплялись и становились традицией. Толерантное, в духе согласия отношение к представителю этноса-соседа стало в регионе привычным, традиционным.

Ключевые слова: этнос; этнос-старожил; межэтническая толерантность; межэтническое согласие; Бурятия; буряты; русские; традиция; стереотип; фактор.

\section{Для цитирования}

Чимитова И. 3., Серебрякова Ю. А. Межэтническая толерантность и согласие как традиция Бурятии // Вестник Бурятского государственного университета. Философия. 2019. Вып. 4. С. 64-70.

Актуальные для современности межэтническая толерантность и согласие формируются и поддерживаются в обществе под влиянием разного рода факторов, некоторые из которых рассматривались нами ранее $[1,2]$.

В литературе понятие «фактор» нередко раскрывается как движущая сила, причина какого-либо явления или процесса или существенное обстоятельство, влияющее на их возникновение, бытование или протекание, что соответствует значению этого слова, восходящего к латинскому factor - делающий, производящий.

Социальные явления и процессы испытывают воздействие многих обстоятельств. В отличие, например, от условий, тоже оказывающих на них влияние, 
факторы связывают с большей целенаправленностью, планомерностью, поэтому под понятием «фактор» применительно к обществу часто имеется в виду тот или иной социальный институт.

Социальные факторы, воздействующие на уровень межэтнической толерантности и согласия, дифференцируются на общесоциальные, влияющие на социум в целом, которые можно назвать макрофакторами, факторы среднего уровня, в качестве которых нередко выступают социальные институты (образование, СМИ, семья и т. д.) и которые выступают в качестве мезофакторов, и микрофакторы (конкретная семья, трудовой коллектив и т. п.).

В качестве одного из факторов межэтнической толерантности и согласия применительно к ряду российских регионов, в том числе Бурятии, можно рассматривать традиции позитивного межэтнического взаимодействия, сложившиеся там.

Прежде чем обратиться к этой проблеме, кратко остановимся на содержании понятия «традиция».

Благодаря фундаментальным работам, в том числе отечественных ученых, традиция в гуманитарном дискурсе второй половины прошлого века перестала быть синонимом архаики. Ее стали связывать с областью духовной жизни (А. И. Новиков, В. А. Малинин и др.), изучать ее социальные роли (И. В. Суханов, Н. П. Денисюк и др.), рассматривать в плане отношений между стадиями развития (А. Г. Спиркин), прошлым и настоящим (П. Штомпка и др.), как зафиксированный, определенным образом организованный и упорядоченный опыт исторической общности, служащий основой движения вперед (Э. С. Маркарян, Б. М. Берншнейн и др.), способ развития культуры, социальную связь субъектов, процесс функционирования и механизм социальной регуляции и передачи от поколения к поколению накопленного опыта (С. А. Арутюнов, В. Б. Власова и др.), единство консервативной и новаторской сторон (В. Б. Власова и др.).

Иначе говоря, современная наука на новом уровне вернулась к принятому у мудрецов древности, прежде всего у Конфуция, толкованию традиции в связи с представлением о преемственности прошлого и настоящего, интерпретируя ее как одно из проявлений поступательного характера развития общества, каждая ступень которого подготовлена предшествующими. Обратимся непосредственно к рассмотрению традиций межэтнической толерантности и согласия, сложившихся на территории этнической Бурятии.

В Бурятии благоприятные межэтнические отношения, в том числе между крупнейшими по численности народами - бурятами и русскими, являются традиционными в силу нескольких причин. Прежде всего, следует отметить изначальную готовность к контактам, сложившуюся в первой половине XVII в. у численно доминирующих среди аборигенов этого региона монгольских племен с первопроходцами-представителями Российского государства.

Некоторые специалисты подчеркивают значение в первоначальных контактах пришлых и бурят как представителей монгольского мира психологического фактора: «положительного отношения монгольского мира к полпредам Белого царя - хозяина одной из окраин когда-то существовавшей империи - Золотой орды» [3, с. 101].

В свою очередь, первопроходцы к крупным этническим группам относились лояльно. По мнению Л. Р. Павлинской, «обитавшие в сибирской лесостепи народы были готовы к контакту с новым этносом. Хотя эта готовность не исключала на 
первых порах определенной психологической несовместимости, вызванной значительным различием культур... она... исключала нетерпимость к новому иноэтническому присутствию» $[4$, с. 9$]$.

Более того, постоянные нападения монголов на Байкальский регион, где уже расселились предки бурят, способствовали переходу коренного населения на сторону русских совместным выступлением бурят с последними.

При оценке состояния отношений между народами региона следует учитывать роль такого объективного фактора, как природно-географический: Байкальский регион несколько веков назад представлял собой колоссальную по своим размерам территорию, с суровым большую часть года климатом и редкими и малочисленными поселениями.

В этих достаточно трудных, в первую очередь для уроженцев европейской части России, да и для в большинстве своем ранее переселившихся из более южных широт монгольских племен, условиях малочисленные коллективы людей разного этнического происхождения отчасти вынуждены были, а позже и осознанно стремились к сотрудничеству, оказывали друг другу помощь, достигали взаимопонимания. Так зарождались и складывались в процессе взаимодействия традиции толерантности и согласия.

В сознании представителей каждого из контактирующих этносов складывался образ «другого», представителя этноса, с которым постоянно вступали во взаимодействие, в процессе которого отрабатывались алгоритмы реакций и поведения в типичных ситуациях, определенные правила, нормы и т. д. На первых поpax этого было достаточно для решения насущных задач. Наиболее адекватные образы и самые удачные алгоритмы закреплялись и становились традицией.

Через механизм традиции как принципиально важного внутреннего фактора Г. Абдулкаримов объясняет содержание процесса формирования толерантности или интолерантности. Они могут быть и эмпирическим продуктом собственной рефлексии индивида, но чаще «формируются в процессе социализации как присвоения субъектом ранее накопленного и переведенного в социокультурную традицию коллективного опытного знания... Благодаря традиции формируется и становится стереотипом "образ" (паттерн) "другого"... закрепляются в традиции представления о допустимости/недопустимости... социальных групп... и присущих им культурных черт отражают уже установившуюся социальную структуру и сложившиеся социальные отношения, то есть такое состояние социума, при котором доминируют интеграционные тенденции» [5, с. 169].

Термин «интеграция» используют многие авторы, характеризуя межэтнические коммуникации в Бурятии, отмечая нарастание интеграционных процессов и их доминирование в современных условиях [См., напр.: 3, с. 102].

Аналогичными механизмами характеризуется и формирование межэтнического согласия.

Принципиально важным в природе традиции является свойственная ей стереотипность, следование стандартам, своего рода автоматизм, побуждающий человека действовать по привычному, общепринятому образцу, иногда подсознательно, что выражает существо консервативной стороны традиции. Не случайно при анализе традиции часто рассматриваются стереотипы, стандарты, образцы, привычки и т. д. Так, В. Б. Власова подчеркивает однопорядковость, формализм 
действий и стандартность реакций: «...через традицию устанавливается по крайней мере относительная и ограниченная согласованность и однопорядковость действий людей, принадлежащих к одному и тому же историческому поколению, но к различным общественным группам, поскольку составляющая ее содержание социальная связь реализуется на практике через сопряженные друг с другом стандарты реакции и формализм действий» [6, с. 36].

Об этом же пишет П. Штомпка: «Традиции обеспечивают людей, формирующих свой мир, готовыми "строительными блоками"... Некоторые традиции поддерживаются скорее на уровне "социального подсознания", в силу привычки и инерции» $[7$, с. 95,97$]$. Следовательно, толерантное отношение к представителю этноса-соседа, более того, поведение в духе согласия, дружелюбное стало привычным, традиционным. Со временем познание этнического «другого» у народов Бурятии расширялось, углублялось, обнаруживались черты сходства или близости с собственным образом действий и мыслей, что еще более объединяло народы. В процессе близкого взаимодействия многое становилось их общим достоянием.

Соседство и совместная деятельность народов обусловили полномасштабное взаимное влияние, в том числе заимствование элементов культуры друг друга. Так, буряты, знакомые с земледелием и до прихода русских, углубили свои знания и умения, постепенно перешли к оседлости. Русские позаимствовали опыт природопользования бурят, эвенков и других аборигенов, освоили особенности скотоводства, охоты и других промыслов в местных условиях. Имел место обмен орудиями, продукцией, практическими навыками, элементами духовной культуры, лексикой, распространялось двуязычие. Межэтнические отношения II половины XIX в. историки называют «дружбой и сотрудничеством» [8, с. 252].

Немаловажное значение в формировании толерантности и согласия между народами имел демографический фактор. Приблизительно с середины XVII в. начались процессы межэтнического смешения, более слабым оно было у старообрядцев, достаточно выраженным - у других групп русского суперэтноса, особенно казаков. Постепенно смешанные браки стали обычным явлением. Их следствием стало то, что многие русские имели родственников и предков-бурят, и наоборот.

В результате этих процессов появились «целые поселения, заселенные метисами, свободно владеющими русским и бурятским языками... Смешанные браки, завязывавшие узы родственных отношений между русскими и бурятскими семьями, вели зачастую к основанию прочной дружбы между ними» [8, с. 113].

Исключительно заботливое отношение аборигенов к детям обусловило распространенность института приемных детей, которых брали и воспитывали, особенно бездетные пары, не только у родственников и соплеменников, но и из многодетных русских семей.

Распространенность усыновления в брачно-семейной культуре аборигенов региона была воспринята местными русскими, принимавшими в свои семьи детейбурят, дававшими им русские имена и фамилии. Впоследствии эти дети часто женились на русских женщинах.

Межэтническая толерантность и согласие представителей оседлового, земледельческого и кочевого миров, разной расовой принадлежности не могли сложиться быстро и беспроблемно, несмотря на свойственную этим народам, по убеждению Л. Н. Гумилева, взаимную комплементарность. 
Традиции межэтнической толерантности и согласия складывались постепенно. А. П. Щапов так писал об этом: «...мало-помалу окончательно водворилось мирное дружелюбное сообщение русских и бурят, и в случаях взаимной вражды и тяжбы из-за хищничества и насилий, в конце концов, закрепилось мировыми записями и т. п. - то взаимная социальная симпатия или сожительно-бытовая общительность между русскими и бурятами постепенно все более расширялась» $[9$, c. 255].

Сложившиеся ранее традиции толерантности и согласия между этносамистарожилами Байкальского региона сохранились и в советский период.

Официально проводимая в СССР политика интернационализма, несмотря на абсолютизацию классового принципа, этническую унификацию и курс на создание новой исторической общности - советского народа, внедрял в практику и содержательные ценности и модели поведения.

В регионе была создана Бурятская автономная республика, два бурятских национальных округа, преодолена отсталость практически во всей сферах жизнедеятельности, оказывалась особая государственная поддержка малочисленных народов, т. е. протекали модернизационные процессы. Что касается интернационализма, то в Бурятской АССР, Усть-Ордынском и Агинском автономных округах его не потребовалось как-то специально продвигать, поскольку межэтническая толерантность и согласие (по сути, имеющие много общего с интернационализмом) на этой территории, а также во многом в сопредельных областях Байкальского региона уже давно стали традицией.

По данным переписи 1979 г., смешанных семей в республике было 8,9\%. «Межнациональные браки и семьи - один из важных результатов тесного общения национальностей, живущих в дружбе и согласии», - комментировал эти результаты В. И. Затеев, который также привел итоги социологического исследования начала 1970-х гг., в соответствии с которым «три четверти опрошенных в целом одобрили межнациональные браки, рассматривая их как живое проявление тесного общения, дружбы и взаимного уважения советских людей различных национальностей» $[10$, с. 150].

Некоторые авторы подчеркивают особый вклад в позитивный характер межэтнических отношений в регионе, сделанный именно в советское время. Например, по мнению Э. Д. Дагбаева, «ровные и добрососедские отношения между основными этническими группами были обусловлены тем, что годами на забайкальской земле сложилось равноправие, особенно в советский период, когда ряд политических шагов государства... позволил достичь сбалансированного уровня развития крупнейших этнических групп. Историческая память народов сохранила примеры взаимопомощи и взаимовыручки, она не омрачена событиями межнациональных распрей и конфликтов...» [11, с. 22].

Полагаем, политика Советского государства в области национальных отношений отличалась большей последовательностью и опиралась на более солидное идейное обоснование, нежели политика предшествующих этапов развития России.

Во всяком случае в Бурятии обозначаемые таким идеологическим конструктом, как «интернационализм», отношения были (и во многом остаются) социальной реальностью. 
Традиции дружбы этносов-старожилов сохранилась в регионе и в постсоветское время. На них не повлиял кратковременный всплеск национализма, имевший место в ходе перестроечных процессов.

Таким образом, межэтническая толерантность и согласие являются в Бурятии давней и прочной традицией, одним из факторов стабильности и устойчивости отношений между разными этническими группами. Сложившись в отношениях между народами-старожилами региона, она была воспринята и представителями других народов, селившихся в разное время на ее территории, выступая тем самым одним из важнейших факторов этой стабильности.

Лuтература

1. Чимитова И. 3. Средства массовой информации как фактор воздействия на уровень межэтнической толерантности // Вестник Бурятского государственного университета. Сер. Философия, социология, политология, культурология. 2011. Вып. 14. С. 117-122.

2. Чимитова И. 3. Образование как фактор укрепления межэтнической толерантности // Вестник Бурятского государственного университета. Сер. Философия, социология, политология, культурология. 2015. Вып. 14(1). С. 62-66.

3. Карнышев А. Д., Винокуров М. А. Человек и этнос на своей земле (экономика и психология самобытности и сотрудничества народов Байкальской Сибири). Иркутск: Издво Байкальского гос. ун-та экономики и права, 2011. 348 с.

4. Павлинская Л. Р. Буряты. Очерки этнической истории. СПб.: Европейский дом, 2008. $256 \mathrm{c}$.

5. Абдулкаримов Г. Теоретические проблемы актуальной этнополитики в России: этносоциология модернизации современной России. М.: Весь мир, 2008. 336 с.

6. Власова В. Б. Традиция как социально-философская категория // Философские науки. 1980. № 4. С. 30-39.

7. Штомпка П. Социология социальных изменений: пер. с англ. / под ред. В. А. Ядова. М.: Аспект Пресс, 1996. 416 с.

8. История Бурятии: в 3 т. Т. II. XVII — начало XX в. Улан-Удэ: Изд-во БНЦ СО РАН, $2011.624 \mathrm{c}$.

9. Щапов А. П. Эгоистические инстинкты в Ленской народной общине: бурятской улусной, оседло-инородческой и русско-крестьянской (Отрывок из IV главы «О Ленской общине» (1875 г.) // Собр. соч. Иркутск: Восточносибирское областное изд-во, 1937. Доп. том к изд. 1905-1908 гг. С. 224-257.

10. Затеев В. И. Диалектика национальных процессов в СССР. Улан-Удэ: Бурят. кн. изд-во, 1989. $160 \mathrm{c.}$

11. Дагбаев Э. Д. Социокультурное развитие бурятского сообщества в начале XXI века // Бурятская литература в условиях современного социокультурного контекста: материалы региональной науч. конф. (27-28 ноября 2006 г.). Улан-Удэ: Буряад унэн, 2006. Ч. І. C. $14-26$. 
INTERETHNIC TOLERANCE AND CONSENT AS A TRADITION OF BURYATIA

Irina Z. Chimitova

Cand. Sci. (Sociol.), Senior Lecturer,

Filippov Buryat State Agricultural Academy

8 Pushkina St., Ulan-Ude 670024, Russia

E-mail: rindaol@mail.ru

Yulia A. Serebryakova

Dr. Sci. (Philos.), Prof.,

Filippov Buryat State Agricultural Academy

8 Pushkina St., Ulan-Ude 670024, Russia

E-mail: serebr.yu.a@yandex.ru

The traditions of positive ethnic interaction are one of the factors of interethnic tolerance and consent in a number of Russian regions, including Buryatia. In Buryatia such relations between Buryats and Russians are traditional for several reasons: the initial readiness of aboriginals for contacts with arrivals, the specifics of natural and geographical conditions, neighbourliness and cooperation of the peoples. It was resulted in experience exchange, mixed marriages, etc. The algorithms of behavior, certain rules, and norms were developed in the process of constant interaction, which became stereotypes; the mutual images of another people were formed in the consciousness. The most adequate images and the most successful algorithms were fixed and became a tradition. Tolerant attitude towards the representative of another ethnic group had become traditional in the region.

Keywords: ethnos; long-standing ethnos; interethnic tolerance; interethnic consent; Buryatia; Buryats; Russians tradition; stereotype; factor. 